\title{
Staller Game for Vocabulary Building
}

\author{
G.A.P. Suprianti ${ }^{1}$, Ni Nyoman Padmadewi ${ }^{2}$, I Nyoman Laba Jayanta ${ }^{3}$, Luh Wayan Fatini ${ }^{4}$ \\ \{gap.suprianti@undiksha.ac.id ${ }^{1}$,nym.padmadewi@undiksha.ac.id ${ }^{2}$, laba.jayanta@undiksha.ac.id ${ }^{3}$, \\ gekpipit208@gmail.com $\left.{ }^{4}\right\}$ \\ Universitas Pendidikan Ganesha, Indonesia ${ }^{1234}$
}

\begin{abstract}
This study aimed at: 1) developing Staller Game Board in building English vocabulary to the learners. 2) knowing the quality of developed Staller Game. This study was a RnD (Research and Development). The subjects of this study were the 8th grade students. The object of this study was the Staller Game. This study used several instruments namely interview guide, field note, observation checklist, expert judgment rubric, and questionnaire. The data were analyzed by qualitatively and quantitatively. The result showed that: 1) Staller game board is a game that was played on a board by rolling the dice and taking cards to solve. This game provides 4 different kinds of card and 3 kinds of challenges in it. Those cards are Ordering Story, Answering Question, and Solving Challenge, and provide a Bonus card. The game takes a theme 'Thing around you' (related to descriptive text). The game was also equipped with a manual book. 2) The judges agreed that the game is categorized as an excellent game.
\end{abstract}

Keywords: Teaching vocabulary, board game, Staller Game

\section{Introduction}

Talking about teaching English it also means talking about vocabulary. The first major in learning English is learning vocabulary. Teaching English vocabulary will be difficult in Indonesia because English is not used in daily language communication. That becomes a consideration in using various strategy in teaching English. Direct instructions only make the students become confused. Which how in the process of producing a word, learners should know the meaning or concept what they want to express on their mind which word will be selected [1].

Adolescence learner must have challenge to provide a new knowledge [2]. Most teenager search for their individual identity and provide themselves to the challenge [3]. Based on thus statement of research, giving challenging activity can prove the process of accepting new knowledge and build a concept or meaning for the students. Activities donein the classroom should be planned in such a away, for instance, by giving game.

Game is the best way to charge students motivation during the difficulties lesson in the classroom. In addition, games create a fun and relaxed atmosphere where young learners could learn fast and retain words better[4].A game has crucial role to in improving motivation[5]. Besides, game also give a space for the students to do some moving. Moving helps the students relax their position. This statement is in line with a statement about fun games are a great way to revive students' interest in the class[6].

Advantages of giving game in the classroom during learning process are; (1) Game can share fun feeling through the students. Feeling can move better if the teacher can share an 
attractive activity in the class such as game. Game also helps to reduce students stressful. (2) Game gives a space to the students to do interaction with teacher or other students. Game provides students to interact each other including the teacher. When the game is played, students as a player should interact each other to solve the problem. (3) Game provides a challenge to the students. As a teenager, students are able to comprehend more new knowledge by putting them into a challenge [3]. Activity such as guessing, answering, transferring or finding out to solve the problem which create in the game can make a challenged feeling to the students. This situation can make long history for students to remind [7]. (4) Game is a learning activity with putting knowledge inside it. Game said a good game when it can make the students become more focus during learning process [8]

Staller Game is a game adapted from a movie game named Jumanji. This movie is released in 1999. Jumanji is a game asking the player to run the pawn in an edge of the board. In the process to be the winner, the player will get a card with the instruction or problem to solve. Staller Game adapts this game to create a new innovation in learning vocabulary. By using the same rule, Staller Game was then created to help the teacher enrich students' vocabulary. The level of this game suits the level of adolescence learner.

\section{Method}

The research was conducted at SMP N 2 Sawan, which is located at Bungkulan Village, Sawan, Buleleng Regency. This research was conducted in class $8 \mathrm{~A}$ with the total of 31 students This research was a research and development. Research and development is a research method which issued to creating a product and test the effectiveness of the product [9]. The design proposed generallyhas 10 steps to development study, but only 5 steps that used in this study until create a prototype of the product. Thus steps are identifying potential and problem, collecting data, designing product, validating data, and revising the product.The object of this study was the Staller Game. The data were taken from the need analysis through the school and class situation, syllabus checking, designing the product, and expert judgment qualities. The teacher was observed and interviewed and the students filled up the questionnaire. The instrument used in this research were interview guide, field note, observation checklist, expert judgment rubric, and questionnaire. The procedure of data collection were conducting initial meeting with the English teacher, conducting classroom observation, identifying of the problem, checking syllabus, designing the product, and validating the product to expert judges.Then, to find out the quality of the product, the researcher used a formula from Nurkancana and Sunartana [10]. The research data set can be accessed in osf.io Open Science Framework.

\section{Finding and Discussion}

In the process of need analysis, the researcher distributed questionnaires to the students and doing observation in the classroom. In this process, it was found that eighth grade students in SMPN 2 Sawan had low interest in learning English. The low interest of learning were found due to the way of English teacher taught the students. Teacher use monotone way to 
teach the students by giving direct instruction (lecturing) and answering the task. This situation could easily make the students became quickly bored and has less motivation.

Looking from this situation of the students, giving a game as an enrichment could be a good innovation to be applied in the classroom. Giving game was a great way to revive students' interest[6]. Besides, game also put the students into a challenge. The teacher needed a strategy to package the game before it is applied in the classroom. The strategy used in applying a game can help the teacher to enrich students' knowledge especially to enrich vocabulary on their mind store. Vocabulary plays a major role in learning English [7].

Document analysis was a step of syllabus checking to take the basic competency for developing the game. This step had a purpose to compare the syllabus used with the vocabulary that needs to be developed by using game. It was done by checking the syllabus on the year of academic 2017/2018.

Based on the syllabus used, researcher found 2 basic competences in 2 skills suggested to be taught by using game. Those skills were reading and speaking. Reading skill with the basic competence 5.1 about meaning respond and rhetorical step for short and simple text accurately, fluently and accepting which connecting to surrounding in the descriptive and recount text, and speaking skill with the basic competence 4.2 about meaning expression in the short and simple monolog by using kind of oral language accurately, fluently and accepting to integrated with surrounding in descriptive and recount text.

Playing a game should be clear. Staller game board was created so visible and also the pictures chosen were clear and communicativeHarmer (2007). The process of editing the product was done by using Coral Draw X7, Adobe Photoshop CS 6, and Microsoft Office Word 2010. The board design was created on Coral Draw X7. The cards design were created on Adobe Photoshop CS 6. The last was Microsoft Office Word 2010 used to create the manual book and the answer key. Those applications were really beneficial in creating a good graphic and choosing the applicable size. Choosing the size of the product was adopted from the size of the game named Chess Board. The size of the board is $30 \mathrm{~cm} \mathrm{X} 30 \mathrm{~cm}$. This size was chosen since it would be very handy to be applied in the classroom and easy to be seenby the student. The board provided with an iron sheet. The size of the card was less than $10 \%$ of the board itself; there was $7.4 \mathrm{~cm}$ X $5.3 \mathrm{~cm}$ and the manual and answer keys with the size 8.2 $\mathrm{cm}$ X $6 \mathrm{~cm}$. The pawnsusedwere $3 \mathrm{~cm}$ height with the diameter $1.5 \mathrm{~cm}$. The pawns were provided with a small magnet to make it stay stand in the board. The size of the dice is $2 \mathrm{~cm} \mathrm{X}$ $2 \mathrm{~cm} \times 2 \mathrm{~cm}$.

In relation to the vocabulary enrichment, Staller Game Board was an innovation game to enrich students' vocabulary during learning process. In the process of developing this game, there were four different parts of card in one board design. Those cards can be played in one time. The material taken based on the last material applied in the classroom when the preliminary observation happened, that is, descriptive text. In this game, things to be describedwere chosen to be developed. 


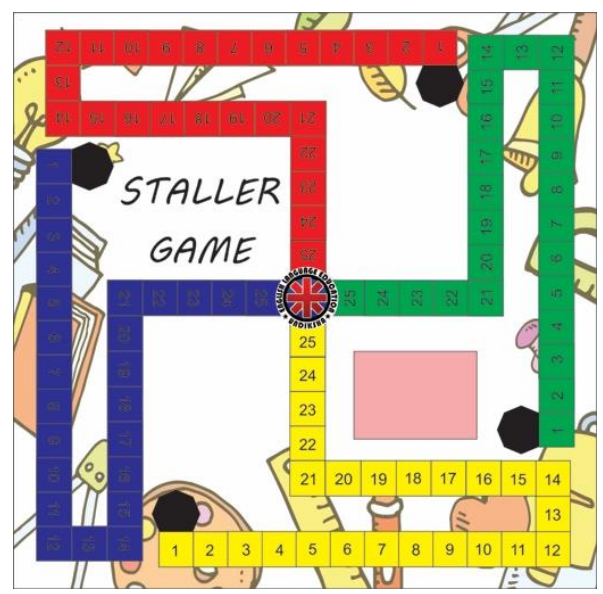

Fig. 1The Design of Staller Game Board

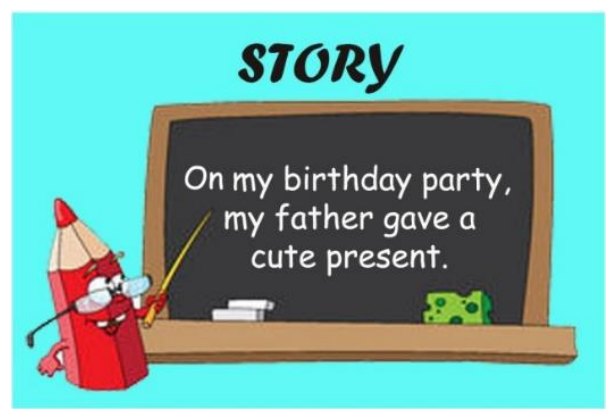

Fig.2The Design of Ordering Story Card

To play this game, the students had to play in a group. The students needed to understand the different instruction in each different color of card. There were four different colors provided in a board. The four different color of card were the blue card of Ordering Story, the red card of Challenge, the yellow card of Question and the green card of Bonus.

In Ordering Story, the students will be leaded to order the descriptive text. The students will learn how to write down and order the descriptive text in a correct way.

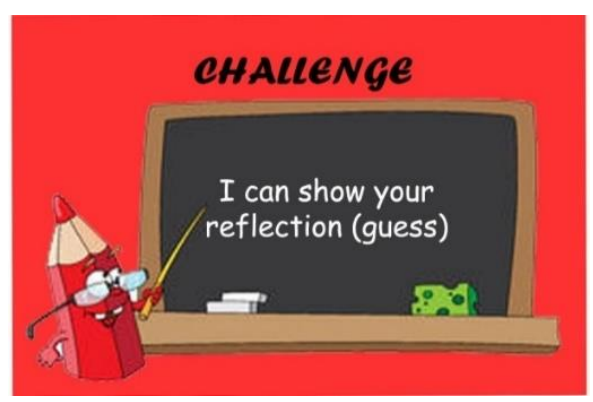

Fig. 3The Design of ChallengeCard

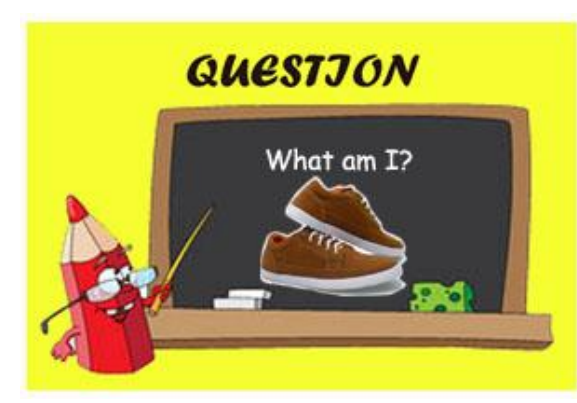

Fig.4The Design of Question Card

Then in the Challenge card, the students will be leaded to learn the name of the things around by guessing from the clue typed in the card.

Next is Question card. This card led the students to observe the story or the pictures. Students should answer the question correctly. 


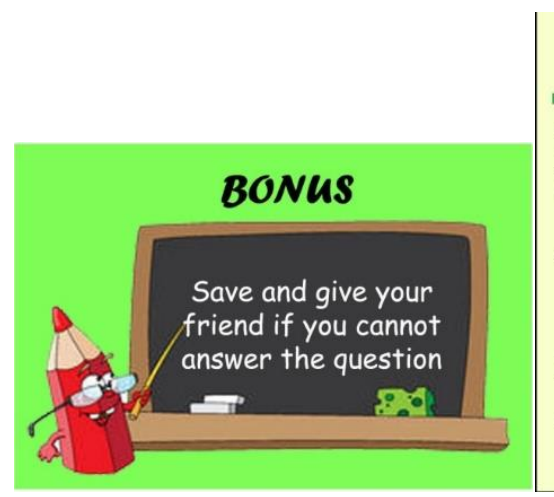

Fig. 5The Design of Bonus Card

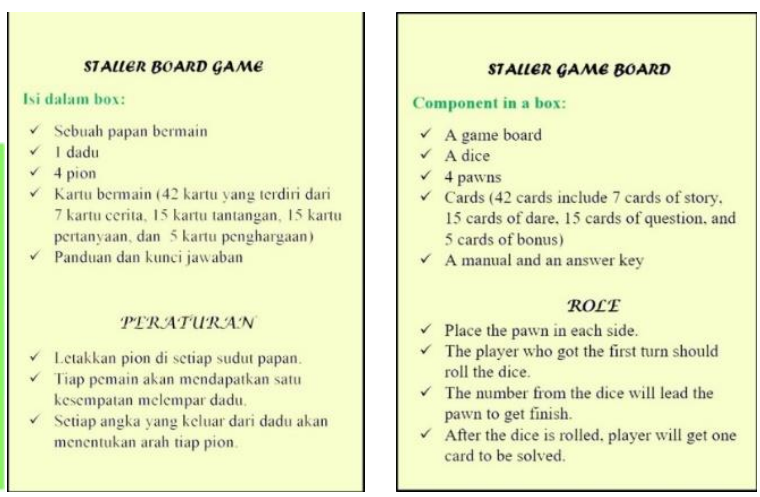

Fig.6The Design of Manual Book

The last is Bonus card. This card functioned to keep the player from a difficult card which they might get.

The students could feel the experience of learning by giving each students to try (speak, listen, read, and write) what they got from the card. Card in this game led the student to do things based on the instruction. Those different parts of card were developed to give different situation for the students and reduce a boredom of the students with the same kind of card. The use of pictures can create students' imagination with the thing around them. Another important point one of this product is a set of manual and answer key. The manual will help the leader to lead the game running and the answer key help the leader to revise the students' answer (if there is any mistake).

The manual was provided in two languages, that is English and Indonesian, to make the player become easier to learn. The quality of the product was determined by the expert judges. The expert judgesconducted the evaluation of the product. The expert judgesstrongly agreed with this game. Based on 2 expert judges, this game can be applied through the 8th grade of junior high school. The process which following the judgement was revision. Most of the revision was on the grammar error and some design of using the pictures. The calculation of the expert judgesused Likert Scale theory. Based on the calculation that was done previously, this game was agreed to apply for the 8th grade students. Finally, this game was categorized as an excellent media [10]. That was shown from the total result of first expert judgesand second expert judges. The total score of first expert judgment was 106 and the second expert judgment was 108. Based on the calculation, the scores were categorized as an excellent media.

The final product of this development was a prototype of a Staller Game Board. This game consisted of a dice, 4 pawns, total of 42 cards which consisted of 7 cards of story, 15 cards of challenge, 15 cards of question, and 5 cards of bonus, and a manual and answer key with the total of 17 pages. The theme for this game was describing thing. The things chosenin the cards were the things around the students, such as umbrella, hat, shoes, pencil, and many more. Those things were selected based on the syllabus used in the 8th grade of junior high school.

The developed game had some strength. The first, this game is suitable to be applied in the teaching and learning process for 8th grade junior high school. This game is suitable because the material was taken from the syllabus. Second, each thing applied in this game was adapted from the things found around the students' daily life. So that, the students can easily find the vocabulary hidden in the clue. Third, the game is colorful and uses a lot pictures that 
can make the students become enjoyable to play the game. Fourth, the game provides the students chance to move during the teaching and learning process. The activity will make students enjoy, reduce their boredom in learning and able to learn through playing.

The challenge when playing this game also needed to be noticed. It is true that the basic functions of a game is to make a fun situation and facilitate the students to learning, but playing game can make the student lose control. When playing the game, the teacher should make a deal in the beginning before the game was started, such as giving reward as well as punishment for each activity conducted in the classroom. This is important to reduce a noisy situation which may happen during the classroom activity. The other situation is it takes longer time to play a game. Therefore, the teacher should be wise in managing the time of playing the game while inserting the concept in the lesson. Not only for playing, this game also facilitates the teacher to make a media in the form of the card used in this game. Each card facilitates one vocabulary. So, in each turn of taking a card teacher can also deliver the lesson and ask the students to describe things. The game also facilitates a story that can be used to write a correct descriptive text. By doing this activity, the teacher will have enough time to explain the material.

\section{References}

[1] M. Alqahtani, "The Importance of Vocabulary in Language Learning and How to Be Taught," Int. J. Teach. Educ., vol. III, no. 3, pp. 21-34, 2015.

[2] D. Nunan, Second language teaching \&amp; learning. Heinle \& Heinle Publishers, 1999.

[3] J. Harmer, The Practice of English Language Teaching. Pearson Longman, 2007.

[4] S. A. Bakhsh, "Using Games as a Tool in Teaching Vocabulary to Young Learners," English Lang. Teach., vol. 9, no. 7, p. 120, 2016.

[5] N. W. S. Mahayanti, G. A. P. Suprianti, and I. P. I. Kusuma, "Language Learning Games Development Based on Curriculum 2013," J. Educ. Technol., vol. 1, no. 1, pp. 61-70, 2017.

[6] M. Rohani and B. Pourgharib, "The Effect of Games on Learning Vocabulary," Int. Res. J. Appl. Basic Sci., vol. 4, no. 11, pp. 3540-3543, 2013.

[7] M. Alemi, "Educational Games as a Vehicle to Teaching Vocabulary," Mjal, vol. 2, no. 6 October, pp. 425-438, 2010.

[8] J. C. Richards and T. S. (Theodore S. Rodgers, Approaches and methods in language teaching. Cambridge University Press, 2001.

[9] Sugiyono, Metode Penelitian Pendidikan; Pendekatan Kuantitatif, Kualitatif, dan R\&D. Bandung: Aflabeta Bandung, 2015.

[10] W. Nurkancana and P. Sunartana, Evaluasi Hasil Belajar. Surabaya: Usaha Nasional, 1992. 